\title{
PENGARUH TEKNIK BERMAIN PERAN TERHADAP KETERAMPILAN BERBICARA
}

\author{
Agung Prasetyo, Doni Anggoro Ari Santoso \\ Program Studi Pendidikan Bahasa Inggris, Fakultas Bahasa dan Seni \\ Universitas Indraprasta PGRI \\ Aprasetyo20@gmail.com;don.okba@gmail.com
}

\begin{abstract}
Abstrak
Penelitian ini dilakukan dengan tujuan agar peneliti dapat secara empirik apakah keterampilan berbicara siswa yang diajarkan menggunakan teknik bermain peran lebih tinggi dibandingkan para peserta didik yang mendapatkan pengajaran melalui metode konvensional (diskusi) peserta didik kelas VI Madrasah Ibtidaiyah Al Falah Bogor. Metode eksperimen digunakan sebagai metode penelitian dalam penelitian ini. Sampel yang digunakan untuk penelitian ini adalah dengan menggunakan teknik random sampling dengan jumlah sampel dari 60 siswa. Instrumen dalam penelitian ini menggunakan tes non-lisan berjumlah 20 soal. Analisis data menggunakan statistik deskriptif, uji syarat data yakni uji normalitas serta homogenitas dan juga uji kesamaan dua rata-rata. Hasil pengujian hipotesis ini diperoleh melalui uji kesamaan dua rata-rata ( uji t) pada taraf signifikan 5\%. Dari hasil analisis data diperoleh rata-rata skor kelas eksperimen $=78,7$ dengan simpangan $=10,28$ sedangkan rata-rata kelas kontrol $=72,6$ dengan simpangan $=11,09$. Hasil pengajuan hipotesis diperoleh $t_{\text {hitung }}=2,202$ dan $t_{\text {tabel }} 2,002378$ karena $t_{\text {hitung }}>t_{\text {tabel }}$ dengan Ho ditolak dan $\mathrm{H}_{1}$ diterima. Dari hasil penelitian dapat ditarik suatu simpulan bahwa teknik bermain peran memengaruhi keterampilan berbicara siswa.
\end{abstract}

Kata Kunci: Teknik Bermain Peran, Keterampilan Berbicara

\begin{abstract}
The research is aimed to find out empirically whether students' speaking skill taught by using role play technique is higher compared to students who are taught by using conventional method (discussion) of students of Class VI MI Al Falah Bogor. Experiment method that was used in this research as the method of study. Sample is taken by using random sampling technique of 60 students. The instrument of the research by using non-oral test of 20 questions. The data analysis by using descriptive statistic, normality homogeneity test. The hypothesis of t test of $5 \%$ significant level. The data analysis result of experiment class of 78,7 with 11,09 deviation. The hypothesis result of $t$ observed is 2,202 and t table 2,002378 because tobserved $>t$ table $\mathrm{HO}$ denied and $\mathrm{HI}$ accepted. It meant that there is an effect of the role play technique towards students' speaking skill.
\end{abstract}

Key words: Role Play Technique, Speaking Skill.

\section{PENDAHULUAN}

Kemampuan dalam menguasai bahasa Inggris adalah salah satu kemampuan dasar yang diperlukan seseorang di dalam era informasi dan globalisasi ini, karena dunia ilmu pengetahuan dan teknologi dalam pengenalan maupun penguasaannya banyak tertulis dan tersampaikan dalam bahasa Inggris. Kenyataan ini mendasari keputusan dan kebijakan pendidikan untuk mulai mengenalkan dan mengajar-kan bahasa Inggris sejak siswa me-ngenyam pendidikan pada tingkat Sekolah Dasar (SD) sebagai bentuk per-siapan dasar bagi siswa. Permendiknas No. 22-23/2006 
menyebutkan bahwa Standar isi dan Standar bagi para lulusan pembelajar bahasa Inggris di tingkat SD/MI harus diarahkan untuk me-ngembangkan keterampilan-keterampil-an

mendengarkan, berbicara, membaca, dan menulis agar para lulusan mampu berkomunikasi dan berwacana dalam bahasa Inggris pada tingkat literasi performative. Pada tingkat Performative, orang dapat menguasai keterampilan menyimak, berbicara, membaca, dan menulis dengan simbolsimbol yang digunakan. Berdasarkan kepada hal ter-sebut, perlu ditetapkan Standar Kompetensi bahasa Inggris bagi SD/MI yang menyelenggarakan mata pelajaran bahasa Inggris sebagai muatan lokal. Kompetensi lulusan SD/MI tersebut selayaknya merupakan kemampuan yang bermanfaat dalam rangka menyiap-kan lulusan untuk belajar bahasa Inggris di tingkat SMP/MTs.

(http://edukasi.kompas.com/read/2012/1 1/13/11331821. Mei, 2014). Oleh karenanya, para peserta didik atau para siswa harus dapat kita kembangkan keterampilannya agar pada tingkat yang diperlukan dalam hal ini tingkat performative dapat menguasai dengan baik.

Tujuan pendidikan bahasa Inggris di SD/MI yang lainnya adalah agar lulusan memiliki kesadaran tentang hakikat dan pentingnya bahasa Inggris untuk meningkatkan daya saing bangsa dalam masyarakat global. Karenanya sebagai pendidik kita harus siap untuk mempersiapkan para peserta didik ini untuk dapat bertahan pada situasi apapun. Program bahasa Inggris perlu memperhatikan manfaat dari pembelajaran bahasa, pilihan bahasa mana yang harus diajarkan, jenis pembelajaran yang akan dipakai, dan sebagainya. Dasar pemikiran yang meyakinkan dan perencanaan yang mantap akan dapat membantu perlunya keberadaan pelajar-an bahasa asing di SD. Bahasa Inggris diberikan di tingkat paling dasar yaitu di sekolah dasar sehingga makin ke depan para peserta didik akan semakin siap dalam hal penguasaan bahasa Inggris.

Dalam pembelajaran Bahasa Inggris utamanya keterampilan berbicara, model yang digunakan adalah model yang dapat mendukung peningkatan keterampilan berbicara siswa. Di dalam kelas sebagai seorang pendidik, kita hendaklah harus dapat memilih dan memilah metode-metode yang maenarik dan mudah untuk dimengerti para peserta didik. Dalam hal menciptakan sebuah pembelajaran yang menyenangkan (enjoyable learning) merupakan sebuah tantangan dimana guru haruslah mampu untuk melakukan suatu pembelajaran itu menarik dan menyenangkan terhadap segala ke-mampuan yang ada menjadi sebuah kekuatan pembelajaran total. Perasaan senang dalam kegiatan belajar karena adanya totalitas untuk aktif berpartisipasi dalam pembelajaran.

Dalam konteks inilah peneliti menduga metode atau teknik pembelajaran yang cocok dan menarik untuk melatih keterampilan berbicara siswa yaitu bermain peran. Model ini dipercaya untuk menciptakan kejadian mengenai keadaan dalam kehidupan nyata untuk sekelompok peserta didik. Dengan adanya kejadian yang kita representasikan dalam kegiatan bermain peran, para peserta didik dapat menampilkan respons secara emosional sambil belajar berdasarkan pada respons orang lain. Kegiatan dalam bermain peran sangat memungkinkan para peserta didik untuk dapat secara gambling mengungkapkan perasaannya yang tidak dapat dikenal tanpa para peserta didik tersebut bercermin pada orang lain. Bermain peran ketika berada 
pada konteks pembelajaran memahami pada dasarnya diskusi setelah pemeranan dan pemeranan itu sendiri adalah hal pokok dan bagian dari pembelajaran. Sehingga simpulan yang dapat ditarik adalah para peserta didik harus dapat belajar dari yang didapatnya dari pengalaman orang lain tentang cara memecahkan masalah yang nantinya dapat dipergunakan untuk mengembang-kan dirinya secara optimal. Berdasarkan pada hal tersebut di atas, model atau teknik pengajaran ini berusaha me-ngurangi peran guru yang terlalu mendominasi pembelajaran atau dengan kata lain guru aktif siswa pasif yang sering dipakai dalam pendekatan tradisional. Model atau teknik bermain peran mendorong peserta didik untuk turut selalu aktif dalam pemecahan masalah, sambil mereka menyimak secara seksama bagaimana orang lain itu berbicara mengenai masalah yang sedang mereka dihadapi dan mencari solusinya.

Model bermain peran ini menduga bahwa dalam tekniknya proses psikologis yang tersembunyi, berupa sikap, nilai, perasaan dan sistem keyakinan, nantinya bisa diungkap pelanpelan dengan cara mencari solusi terbaik dan dapat diangkat ke taraf sadar melalui kombinasi pemeranan secara spontan. Dengan demikian, para peserta didik dapat secara sadar menguji sikap dan nilainya yang sesuai dengan orang lain, apakah sikap dan nilai yang dimilikinya perlu dipertahankan atau diubah. Tanpa bantuan orang lain, para peserta didik sulit untuk menilai sikap dan nilai yang dimilikinya. Solusi yang terbaik harus mereka cari agar dapat terlihat apakah peserta didik memahami makna sebenarnya dari teknik atau model pembelajaran yang mereka lakukan.

Keuntungan yang dapat diperoleh dari model pembelajaran bermain peran ini adalah siswa dapat lebih dimotivasi untuk dapat berperan lebih aktif dan untuk menumbuhkan sikap berpikir kritis dalam kegiatan belajar. Selain itu, para siswa juga mendapat kesempatan untuk memahami permasalahanpermasalahan realitas hidup dalam kehidupan nyata, menemukan pengetahuan baru, dan memungkinkan terjadinya interaksi sosial.

\section{Teknik Bermain Peran}

Tertulis dalam Kamus Besar Bahasa Indonesia (2005: 1158), teknik diartikan sebagai metode atau sistem mengerjakan sesuatu, cara membuat atau melakukan sesuatu yang berhubungan dengan seni. Dengan kata lain, teknik itu dapat kita samakan artinya sebagai suatu cara melakukan sesuatu yang ada hubungannya dengan seni, dimana berbagai metode pembelajaran dapat dikategorikan sebagai seni. Metode juga dapat diartikan sebagai langkah-langkah membuat alat atau media yang digunakan untuk seni. Menurut Sanjaya (2006:126), teknik dalam pembelajaran, bersifat implementasional saat proses belajar berlangsung untuk mencapai sasarannya. Dengan kata lain, teknik sebagai daya upaya, atau usaha-usaha yang ditempuh oleh seseorang guru dalam rangka untuk mencapai suatu tujuan pengajaran dengan cara yang paling praktis, namun tetap harus selalu berpijak pada metode tertentu. Teknik dapat dilakukan saat proses belajar mengajar untuk mendapatkan hasil yang lebih baik. Oleh karenanya, teknik yang paling cocok harus dapat dipilih oleh para pendidik agar sesusi dengan para peserta didik.

Berdasarkan pendapat para ahli di atas, dapat disimpulkan bahwa teknik dalam pembelajaran itu dapat didefinisikan sebagai segala usaha, atau upayaupaya yang dilalui oleh seseorang guru 
atau pendidik untuk mencapai suatu tujuan pengajaran dengan cara yang paling sesuai, namun tetap harus selalu sesuai dengan rujukan atau pijakan pada metode atau teknik tertentu. Teknik membutuhkan metode-metode pendukung untuk membantu kelaancaran pelaksanaan teknik tersebut.

Mulyasa (2004: 139) mendefinisikan bermain peran sebagai salah satu model atau teknik dalam pembelajaran yang dapat digunakan secara efektif dalam pembelajaran. Dalam hal ini, kegiatan bermain peran diarahkan pada cara-cara yang dapat digunakan untuk memecahkan masalah-masalah yang ada sangkut pautnya dalam hubungan antar manusia, terutama hal-hal yang menyangkut kehidupan para peserta didik. Dengan kata lain, melalui model atau teknik bermain peran, para peserta didik mencoba untuk dapat mengeksplorasi hubungan-hubungan antar manusia dengan cara mendemotrasikannya dan mendiskusikannya sehingga secara bersama-sama para peserta didik dapat mengeluarkan perasaan-perasaan, sikap-sikap, nilai-nilai, dan berbagai strategi dalam hal pemecahan masalah.

Joyce dan Weil (2007: 70) menerangkan bahwasanya dengan menggunakan teknik role play, siswa dapat meningkatkan kemampuan mereka untuk dapat menghargai diri sendiri dan perasaan orang lain, mereka dapat belajar perilaku yang baik untuk menangani situasi yang sulit, dan mereka dapat melatih kemampuan mereka dalam memecahkan masalah. Dengan kata lain, Role play adalah uji coba tingkah laku dari orang yang mereka diperankan, yang memiliki tujuan untuk melatih siswa dalam menghadapi situasi yang sebenarnya; melatih praktik berbahasa lisan para peserta didik secara intensif; dan memberikan kesempatan yang luas kepada para peserta didik untuk mengembangkan kemampuan ber-komunikasi.

Menurut Jesness (2004 : 151153),

"role plays simulate different kinds of communication situations that the target group of the test could possibly meet outside the text. Role-play tasks are a way of making communication in a test more versatile because rather than talking to a tester, the examinees take on a new role and a new, simulated role relationship to their communication partner."

Dengan kata lain, metode bermain peran ini lebih mudah diatur karena lebih mengutamakan ekspresi diri. Bermain peran dapat ditemui setiap hari dan memiliki banyak stimulasi yang berbeda tidak hanya satu adegan. Hal ini memungkinkan role playing menjadi bahan ajar yang dapat diubah-ubah dan tetap menyenangkan.

\section{Keterampilan Berbicara Bahasa Inggris}

Menurut Depdiknas (2006 : 4), "keterampilan adalah kemampuan seseorang untuk melakukan sesuatu kegiatan." Maksudnya adalah keterampilan merupakan kegiatankegiatan yang dilakukan setiap hari membutuhkan keterampilan yang didapatkan dari aktivitas gerak yang dipelajari dengan benar. Hal-hal yang dipelajari dengan benar tersebut didapat juga melalui melihat pengalaman diri sendiri maupun orang lain. Kegiatan ini mencakup banyak hal, dan jika seseorang secara berulang-ulang melakukan kegiatan tersebut, maka seseorang akan terampil dalam melakukan hal tersebut.

Menurut Sugiyono (2005: 8-11), "keterampilan dapat kita artikan sebagai kemampuan yang dimiliki seseorang untuk menyelesaikan tugas-tugas ter- 
tentu dengan baik. Semakin baik penguasaan keterampilan, maka pelaksanaannya akan semakin efisien." Dengan kata lain, keterampilan merupakan kemampuan yang harus dikuasai agar seseorang dapat melaksanakan segala kewajiban dan tugasnya agar kegiatan dapat diefisienkan. Penguasaan kemampuan dapat dilakukan jika seseorang melakukannya semakin baik tiap waktunya.

Menurut Finocchiro (2001, 83), "speaking is one or more sound make by human being for purposing of communication." Dengan kata lain, berbicara merupakan suara-suara atau bunyi yang dibuat oleh manusia yang memiliki tujuan agar jalinan komunikasi antar sesama secara lisan dapat terwujud. Berbicara mengutamakan suara yang diproduksi oleh indera pengucap, dimana suara yang dihasilkan dapat digunakan untuk berkomunikasi antara satu manusia dengan manusia yang lain. Sehingga tujuan tujuan utama dari berkomunikasi dapat tercapai.

Menurut Spratt (2011, 43),

"speaking is one the four language skills: reading, writing, listening, and speaking. Speaking and writing are productive skills. Speaking is a productive skill, this skill could be sometimes formal and informal it depends on the speech and the level of formality."

Maksudnya adalah berbicara merupakan kemampuan produktif yang artinya diproduksi dari indera pengucap manusia sebagai suatu hasil (lisan), kemampuan ini dibedakan menjadi formal dan non formal tergantung dari tingkat kesantunannya.

Menurut

Brown

(http://areadge.mec.pt/gramatica/whatsp eakingis. html. Juli, 2014), "speaking is an interactive process of constructing meaning that involves producing, receiving and processing information." Artinya, berbicara merupakan proses interaksi untuk membentuk suatu maksud tertentu dimana dapat digunakan untuk memproses suatu informasi. Informasi yang diproses dalam berbicara dapat diatur untuk melakukan interaksi. Berbicara merupakan proses saling berinteraksi dari membentuk makna yang sangat berhubungan dengan menciptakan, menerima, dan menjadikannya sebagai informasi yang diterima.

\section{METODE PENELITIAN}

Penelitian dilaksanakan dengan menggunakan metode penelitian eksperimen dengan analisis komparasi dua variabel. Satu variabel bebas yaitu menggunakan metode konvensional dan variabel terikat menggunakan teknik bermain peran dimana kedua variabel itu terikat pada hasil keterampilan berbicara bahasa Inggris. Menurut Sugiyono (2009: 3), penelitian eksperimen merupakan metode penelitian yang digunakan untuk mencari pengaruh perlakuan tertentu terhadap yang lain dalam kondisi yang terkendalikan. Dengan kata lain, penelitian ekserimen adalah penelitian yang dilakukan untuk mengetahui pengaruh pemberian suatu treatment atau perlakuan terhadap subjek penelitian. Penelitian dengan mengguna-kan metode eksperimen juga bertujuan untuk membandingkan hasil dari penelitian yang menggunakan metode konvensional dengan yang mengguna-kan metode perlakuan. Proses pe-ngambilan sampel penelitian dilakukan dalam dua tahap; menentukan kelas dengan teknik purposive sampling dan menentukan sampel responden dengan teknik random sampling. 


\section{HASIL DAN PEMBAHASAN}

Berdasarkan penelitian yang peneliti lakukan, sampel dalam penelitian ini berjumlah 60 siswa terdiri dari 30 siswa kelas VI-A sebagai kelas eksperimen dan 30 siswa dari VI-B sebagai kelas kontrol Madrasah Ibtidaiyah Al Falah. Karakteristik responden yang diharapkan adalah berusia antara 11-12 tahun dengan memiliki pertumbuhan fisik dan psikis yang stabil.

Intelegensi yang dimiliki kelas eksperimen adalah tinggi yang dibuktikan dengan nilai rata-rata hasil belajar bahasa Inggris yang baik, sedangkan intelegensi siswa untuk kelas kontrol adalah sedang juga dibuktikan dengan nilai rata-rata hasil belajar bahasa Inggris. Tingkat ekonomi orang tua kedua kelas penelitian adalah sama yaitu dengan kondisi ekonomi yang sedang.

Dari deskripsi data diperoleh bahwa keterampilan berbicara bahasa Inggris yang menggunakan teknik bermain peran dapat dinyatakan bahwa dari 30 siswa diperoleh 7 siswa dengan skor tertinggi dan 5 siswa memperoleh skor terendah. Dari hasil perhitungan diperoleh rata-rata 78,7 , median 80,86 , modus 82, varians 105,75 , dan simpangan baku 10,28. Dengan demikian dapat ditarik suatu simpulan bahwa data tergolong baik dan tidak banyak beragam.

Keterampilan Berbicara bahasa Inggris dengan menggunakan metode konvensional dapat dinyatakan bahwa dari 30 siswa diperoleh 5 siswa memperoleh skor tertinggi dan 1 siswa memperoleh skor terendah. Dari hasil perhitungan diperoleh rata-rata 72,6 , median 69,625, modus 82,35, standar deviasi 123,007, dan simpangan baku 11,09 dengan demikian dapat ditarik suatu simpulan bahwa data tergolong cukup dan tidak banyak beragam. Tingginya rata-rata untuk kelompok eksperimen dibanding dengan rata-rata kelompok kontrol membuktikan bahwa metode grup investigasi lebih dapat diterima dan dapat meningkatkan keterampilan berbicara bahasa Inggris siswa.

Dalam pengujian hipotesis pada taraf signifikan $\alpha=0,05$ diperoleh $t_{\text {hitung }}>$ $t_{\text {tabel }}(2,202>2,002378)$, maka Ho ditolak dan $\mathrm{H}_{1}$ diterima dengan demikian hipotesis teruji kebenarannya dan secara signifikan diterima. Dengan demikian dapat ditarik suatu simpulan pula bahwa terdapat pengaruh positif pembelajaran dengan teknik bermain peran terhadap keterampilan berbicara bahasa Inggris. Rata-rata hasil post test keterampilan berbicara bahasa Inggris yang meng-gunakan pembelajaraan dengan teknik bermain peran lebih tinggi daripada yang menggunakan metode konvensional. Fenomena ini menunju-kan bahwa keterampilan berbicara bahasa Inggris akan meningkat bila siswa diberikan pembelajaran dengan menggunakan teknik bermain peran. Artinya semakin banyak guru meng-gunakan pembelajaran dengan metode bermain peran dalam pembelajaran bahasa Inggris, maka akan menghasilkan keterampilan berbicara bahasa Inggris yang baik pula.

Dari uraian teoretis di atas atau hasil yang diperoleh di atas maka dapat ditarik suatu simpulan bahwa secara nyata pembelajaran dengan menggunakan pembelajaran teknik bermain peran mempengaruhi keterampilan berbicara bahasa Inggris di Madrasah Ibtidaiyah Al Falah Bogor. Hal ini dimungkinkan bahwa penggunaan pembelajaran teknik bermain peran kelompok lebih menarik bagi siswa dibanding dengan mengguna-kan metode konvensional yang kurang menarik dan harus mendapatkan lebih banyak penjelasan. 
Dengan penggunaan pembelajaran metode grup investigasi ini terbukti dapat mempengaruhi keterampilan berbicara bahasa Inggris siswa.

\section{SIMPULAN}

Dari penelitian yang telah dilakukan oleh penulis maka dapat ditarik suatu simpulan bahwa model pembelajaran menggunakan teknik bermain peran sangat berpengaruh terhadap keterampilan berbicara siswa. Berdasarkan hasil penelitian ini maka, penulis menyarankan bagi sekolah untuk menggunakan teknik bermain peran karena hal ini dapat memacu siswa lebih kreatif dan bekerja sama sehingga selalu siap untuk mengikuti materi pelajaran yang selanjutnya. Setiap pengajar dimanapun berada dalam mengajar di kelas harus berupaya untuk menciptakan peserta didik yang aktif yang memahami tentang apa yang diajarkan dan dapat me-nerapkannya dalam kehidupan sehari-hari. Yang sangat penting lagi dari tujuan yang harus dicapai oleh para pendidik adalah, bagaimana membekali siswa dengan keterampilanketerampilan yang lebih berguna bagi kehidupannya di masa yang akan datang, yang sangat dibutuhkan oleh mereka pada era globalisasi nanti. Keterampilan yang sangat berguna itu tidak lain adalah keterampilan berbicara dalam bahasa Inggris. Untuk dapat memenuhi tujuan itu, pendidik sebaiknya lebih kreatif menjadikan pembelajaran tampak lebih sesuai dengan yang ada di masyarakat, dan salah satunya melalui pengajaran dengan menggunakan teknik Role Play. Belajar adalah proses, dan butuh kesabaran di pihak kita. Sebagai pendidik kita harus sabar dalam mendidik para peserta didik agar tercapai tujuan dari pembelajaran itu sendiri.

\section{DAFTAR PUSTAKA}

Depdiknas. (2006). Standar Kompetensi dan Kompetensi Dasar Tingkat $S D$ dan MI. Pekanbaru: Dispora.

Finocchiro, M. (2001). Foreign Language Learner : Guide Prentice Hall. New York: DRegents Publishing Company, Inc

Jesness, J. (2004). Teaching English Language Learners K-12 A Quick Start Guide For The New Teacher. Thousand Oaks, California : Corwin Press Sage Publication Company

Mulyasa, E. (2004). Implementasi Kurikulum 2004 Panguan Pembelajaran KBK. Bandung : PT d Remaja Rosdakarya Offset

Sanjaya, W. (2008). Strategi Pembelajaran Berorientasi Standar Proses Pendidikan. Jakarta : Media Prenada.

Spratt, M. (2011). Teaching Knowledge Test Course Modules 1, 2 and 3. Cambridge University Press UK

Sugiyono. (2005). Metode Penelitian Administrasi. Bandung: Alfabeta.

Tim Penyusun. Kamus Besar Bahasa Indonesia. (2005). Jakarta: Departemen Pendidikan dan Kebudayaan

Internet :

http://eprints.uny.ac.id/9523/3/bab\%202 -08209241004.pdf. Diunduh 20 Juni 2014

http://areadge.mec.pt/gramatica/whatspe akingis. html. Juli, 2014 